\title{
RELASI AKTOR, INSTITUSI DAN LINGKUNGAN KEBIJAKAN PUBLIK : ANALISIS KEBIJAKAN PENDIDIKAN ANTIKORUPSI
}

\author{
1)Tatang Sudrajat, ${ }^{2)}$ Omay Komaruddin, ${ }^{3)}$ Ni'mawati, ${ }^{4}$ Supiana, ${ }^{5}$ Qiqi Yulianti Zakiah \\ Universitas Sangga Buana, Bandung, Indonesia ${ }^{1}$ \\ Universitas Islam Negeri Sunan Gunung Djati, Bandung, Indonesia ${ }^{2}$ \\ Sekolah Tinggi Agama Islam Siliwangi, Bandung, Indonesia ${ }^{3}$ \\ Universitas Islam Negeri Sunan Gunung Djati, Bandung, Indonesia ${ }^{4,5}$ \\ id.tatangsudrajat@gmail.com
}

\begin{abstract}
Abstrak
Korupsi saat ini sudah sampai pada taraf yang mengkhawatirkan, karena telah merambah berbagai sektor kehidupan yang sangat merugikan keuangan negara. Pendidikan diharapkan mampu memberikan bekal mental kepada peserta didik untuk tidak melakukan korupsi. Aspek pencegahan menjadi relevan selain penting pula penekanan terhadap arti penting pemberantasan korupsi. Berbagai kebijakan negara atau pemerintah telah terbit sebagai upaya mempersiapkan generasi muda bangsa yang siap menangkal korupsi. Dalam konteks ini, telah terbit kebijakan publik berupa UU Nomor 20 Tahun 2003, Perpres Nomor 87 Tahun 2017, Permendikbud Nomor 20 Tahun 2018, Pergub Jabar Nomor 60 Tahun 2019 dan Perbup Sukabumi Nomor 62 Tahun 2019 yang memberi perhatian besar terhadap integritas, karakter dan pendidikan antikorupsi. Aspek substansi pengaturan kebijakan tentang pendidikan antikorupsi akan menentukan bagi keberhasilannya ketika diimplementasikan. Dengan metode penelitian yuridis normatif dan kajian kepustakaan, dari perspektif administrasi dan kebijakan publik tampak bahwa di Provinsi Jawa Barat telah terbit kebijakan operasional Pergub Jabar Nomor 60 Tahun 2019 dan Peraturan Bupati Sukabumi Nomor 62 Tahun 2019. Terdapat hubungan keterkaitan antara pemerintah pusat dengan pemerintah daerah sebagai pembuat kebijakan dengan lingkungan kebijakan serta hubungan hirarkis dengan kebijakan tentang pendidikan antikorupsi di tingkat nasional. Regulasi sebagai wujud kebijakan publik yang ditetapkan di Jawa Barat dan Kabupaten Sukabumi berperan strategis dalam turut mewujudkan upaya pemberantasan korupsi.
\end{abstract}

Kata Kunci : kebijakan publik, pendidikan, pendidikan antikorupsi

\begin{abstract}
Currently, corruption has reached an alarming level, because it has penetrated various sectors of life which are very detrimental to state finances. Education is expected to be able to provide mental provisions for students not to commit corruption. The aspect of prevention is relevant in addition to being important as well as the importance of eradicating corrosion. Various state or government policies have been published as efforts to prepare the nation's young generation who are ready to ward off corruption. In this context, public policies have been issued in the form of Law Number 20 of 2003, Presidential Decree Number 87 of 2017, Ministry of Education and Culture Regulation Number 20 of 2018, Governor of West Java Regulation Number 60 of 2019 and Perbup Sukabumi Number 62 of 2019 which pay great attention to integrity, character and education. anti Corruption. Substantial aspects of policy settings on anti-corruption education will determine its success when implemented. With the normative juridical research method and literature review, from the perspective of administration and public policy it appears that in West Java Province the operational policy of the West Java Governor Regulation Number 60 of 2019 and the Sukabumi Regent Regulation Number 62 of 2019 has been issued. policies with policies and hierarchical relationships with policies on anti-corruption education at the national level. Regulation as a form of public policy set in West Java and Sukabumi Regency plays a strategic role in realizing efforts to eradicate corruption.
\end{abstract}

Keywords : public policy, education, anti-corruption education.

PRAJA | Volume 9 | Nomor 1 | Edisi Februari 2021 


\section{A. PENDAHULUAN}

Salah satu permasalahan besar yang dihadapi pemerintah dan bangsa Indonesia adalah korupsi, yang hingga saat ini perkembangannya masih sangat mengkhawatirkan. Nyaris tidak ada satupun segmen kehidupan yang terbebas dari virus korupsi yang saat ini juga termasuk salah satu kejahatan luar biasa. Sudah sejak pemerintahan Presiden Soekarno berbagai upaya telah dilakukan dalam menghadapi penyakit mental manusia yang sangat merugikan keuangan negara ini. Berbagai lembaga telah dibentuk untuk menanggulanginya hingga saat ini dengan hadirnya Komisi Pemberantasan Korupsi (KPK). Berbagai regulasi telah diterbitkan negara/pemerintah sebagai bentuk keseriusan untuk menuntaskan penyakit birokrasi yang menggerogoti berbagai level pemerintahan.

Kaitan ini, sangat wajar bila perhatian diarahkan pula kepada peran penting pendidikan sebagai bidang kehidupan nasional yang diyakini dapat memberikan solusi sistematis dalam upaya pencegahan dan pemberantasan korupsi ini. Terbitnya UU Nomor 20 Tahun 2003 tentang Sistem Pendidikan Nasional, Perpres Nomor 87 Tahun 2017 tentang Penguatan Pendidikan Karakter dan Permendikbud Nomor 20 Tahun 2018 tentang Penguatan Pendidikan Karakter Pada Satuan Pendidikan Formal, merupakan entry point bagi terbitnya regulasi di tingkat provinsi dan kabupaten/kota mengenai pentingnya pendidikan antikorupsi sebagai bagian dari penguatan pendidikan karakter. Di Provinsi Jawa Barat telah terbit Peraturan Gubernur (Pergub) Jawa Barat Nomor 60 Tahun 2019 tentang Penyelenggaraan Pendidikan Antikorupsi Pada Satuan Pendidikan Yang Menjadi Kewenangan Daerah Provinsi Jawa Barat, serta Peraturan Bupati (Perbup) Sukabumi Nomor 62 Tahun 2019 tentang Pendidikan Antikorupsi Pada Satuan Pendidikan Jenjang Pendidikan Anak Usia Dini, Sekolah Dasar, Sekolah Menengah Pertama dan Pendidikan Kesetaraan.

Secara konstitusional, harapan untuk hadirnya pendidikan antikorupsi ini mendapat landasan yang kokoh karena termaktub dalam alinea ke 2 Pembukaan UUD 1945 tentang cita-cita nasional yang pada hakikatnya merupakan visi bangsa dan negara Indonesia, diantaranya tentang kemakmuran. Berkenaan dengan itu, salah tujuan nasional atau fungsi negara yang pada hakikatnya merupakan misi bangsa dan negara Indonesia sebagaimana tersurat dalam alinea ke 4 Pembukaan UUD 1945, adalah fungsi untuk mencerdaskan kehidupan bangsa. Karena itu, negara dengan organ utamanya yaitu pemerintah beserta segenap aparaturnya melaksanakan serangkaian program untuk penguatan metal dan karakter bangsa melalui pendidikan. Hal ini ditujukan untuk menjawab berbagai tantangan dan permasalahan yang dihadapi masyarakat untuk hadirnya pemerintahan yang terbebas dari wabah korupsi, dengan memberi perhatian dengan porsi lebih besar pada penguatan karakter.

Salah satu bidang perhatian pemerintah ini adalah pendidikan antikorupsi yang bersandarkan pada penguatan pendidikan karakter. Dari perspektif administrasi publik, terbitnya UU Nomor 20 Tahun 2003, Perpres Nomor 87 Tahun 2017 dan Permendikbud Nomor 20 Tahun 2018 ini jelas merupakan landasan yuridis yang kuat bagi implementasinya di daerah provinsi dan kota/kabupaten. Dalam kerangka inilah peran pemerintah daerah provinsi dan kabupaten/kota sebagai bagian integral dari Negara Kesatuan Republik Indonesia sangat penting untuk menindaklanjuti keputusan politik negara dan pemerintah di bidang pendidikan ini.

Perspektif ilmu administrasi publik, hadirnya beberapa regulasi tersebut merupakan salah satu wujud dari kebijakan publik (public policy). Menurut Lawrence dan Weber, kebijakan publik adalah 'a plan of action undertaken by government officials to achieve some broad purpose of affecting a substantial segment of a nations citizens' (2014:164). Dengan hadirnya berbagai regulasi ini maka para implementor kebijakan pendidikan di daerah memiliki panduan yang jelas sehingga akan dapat mempermudah tercapainya tujuan kebijakan pendidikan antikorupsi ini. Tentu saja terbitnya berbagai kebijakan publik tersebut tentu bukanlah sesuatu yang datang dengan tiba-tiba. Antara negara/pemerintah dengan lingkungannya, khususnya lingkungan sosial budaya yang sangat dinamis, terjadi hubungan interaksi yang resiprokal. Permasalahan yang ada pada masyarakat berupa masih merajalelanya korupsi dapat menjadi pemicu lahirnya satu bentuk kebijakan publik sebagai solusinya.

Sebagai produk administrasi negara, terbitnya berbagai peraturan di tingkat 
nasional, provinsi dan kabupaten/kota ini lahir atas dasar analisis mendalam para pemangku kepentingan kebijakan terhadap permasalahan korupsi yang multifacet. Karena itu, hadirnya berbagai kebijakan publik sebagai dinamikanya administrasi publik yang area substantifnya terkait pendidikan antikorupsi ini serta implementasinya oleh para agen implementasi kebijakan secara konsisten menjadi sangat penting. Dikatakan demikian karena ekspektasi publik untuk hadirnya pemerintah yang terbebas dari perilaku korup dari waktu ke waktu makin tinggi. Institusi pendidikan diyakini punya peran penting dan strategis untuk mempersiapkan generasi muda bangsa yang sejak awal memiliki komitmen melawan korupsi.

Penelitian ini bertujuan untuk mengelaborasi berbagai aspek yang berkaitan dengan kebijakan pendidikan antikorupsi dalam kaitannya dengan relasi antara aktor, institusi dan lingkungan kebijakan publik. Perspektif kebijakan publik tentang hal ini mengacu pada pendapat Anderson, Jones serta Howlet dan Ramesh mengenai aktor, institusi dan lingkungan kebijakan. Selain itu pada pendapat Dye tentang Sistem Kebijakan dan Bromley mengenai hirarki kebijakan.

\section{B. METODE PENELITIAN}

Kombinasi penelitian yuridis normatif dan studi kepustakaan menjadi pilihan dalam penelitian ini. Menurut Marzuki (2015:47) tergolong penelitian hukum (legal research), atau penelitian hukum normatif atau hukum kepustakaan yang dilakukan dengan cara meneliti bahan pustaka atau data sekunder belaka (Soekanto \& Mamudji, 2015: 13). Penelitian dilakukan terhadap informasi yang didokumentasikan dalam bentuk peraturan sehingga biasa dikenal dengan penelitian analisis dokumen atau analisis isi (content analysis).

Sesuai dengan kepentingan penelitian, data sekunder dalam bentuk berbagai dokumen, undang-undang dan peraturan, berbagai sumber literatur yang berkaitan dengan tema penelitian, dokumen lain yang dicetak, termasuk surat kabar dan majalah dan sumber cetak lain yang relevan, digunakan teknik dokumentasi. Dokumen yang menjadi fokus penelitian ini adalah Peraturan Presiden Nomor 87 Tahun 2017, Peraturan Mendikbud Nomor 20 Tahun 2018, Peraturan Gubernur Jabar Nomor 60 Tahun
2019 dan Peraturan Bupati Sukabumi Nomor 62 Tahun 2019.

\section{HASIL DAN PEMBAHASAN}

1. Profil dan Karakteristik Kebijakan Pendidikan Antikorupsi

Perspektif administrasi publik, sebagaimana dikemukakan para pakar kebijakan publik, bahwa ada legalitas dan dimensi kebijakan dalam administrasi publik, dalam hal ini kegiatan dan pengaturan yang berkaitan dengan pendidikan antikorupsi. Perpres Nomor 87 Tahun 2017, Permendikbud Nomor 20 Tahun 2018, Peraturan Gubernur Jabar Nomor 60 Tahun 2019 dan Peraturan Bupati Sukabumi Nomor 62 Tahun 2019 merupakan wujud nyata kebijakan publik. Ini karena mengandung kepentingan publik berupa kecemasan warga masyarakat terhadap masih tingginya tingkat korupsi sehingga terdapat harapan pada institusi pendidikan untuk turut berperan menanggulanginya.

Perpres Nomor 87 Tahun 2017 yang terbit pada 6 September 2017 dan terdiri dari 18 pasal ini, tidak secara limitatif eksplisit menyatakan tidak lagi berlaku regulasi tertentu berkenaan dengan pendidikan karakter. Namun demikian dalam Pasal 17 dinyatakan bahwa pada saat perpres ini mulai berlaku, peraturan perundang-undangan yang mengatur mengenai hari sekolah dan pendidikan karakter yang bertentangan dengan perpres dinyatakan tidak berlaku. Sebagai landasan hukum perpres secara eksplisit disebut UU Nomor 20 Tahun 2003 tentang Sistem Pendidikan Nasional sebagai sandaran yuridis berbagai kebijakan nasional di bidang pendidikan.

Permendikbud Nomor 20 Tahun 2018 yang terbit pada 7 Juni 2018, terdiri dari 15 pasal yang menjadikan salah satu dasar hukumnya Perpres Nomor 87 Tahun 2017, selain UU Nomor 20 Tahun 2003. Meskipun secara spesifik tidak menyebut adanya pendidikan antikorupsi, tetapi dalam Pasal 2 ayat (1) antara lain disebutkan bahwa penguatan pendidikan karakter dilaksanakan dengan menerapkan nilai-nilai Pancasila antara lain religius, jujur, peduli sosial dan tanggung jawab. Dengan kata lain, pendidikan antikorupsi sangat berkaitan dengan nilai-nilai tersebut. Hal ini dipertegas lagi dalam ayat (2) yang menyebutkan bahwa pendidikan antikorupsi antara lain berkaitan dengan lima nilai utama, diantaranya religiusitas dan 
integritas. Karakter orang yang religius dan berintegritas merupakan modal utama sebagai benteng dari godaan melakukan korupsi.

Pergub Jabar Nomor 60 Tahun 2019 yang terbit pada 18 Oktober 2019 ini terdiri dari 12 pasal serta lampiran berupa petunjuk teknis pelaksanaannya. Substansi yang berkaitan dengan pendidikan antikorupsi diuraikan dalam petunjuk teknis tersebut. Dalam lampirannya, disebutkan pula beberapa hal yang berkaitan dengan pendidikan antikorupsi, diantaranya dasar hukum, ruang lingkup dan kedudukan, konsep pendidikan antikorupsi, mekanisme implementasi, pembinaan, pengendalian dan evaluasi. Selain itu terdapat dalam tujuan pergub tersebut, yaitu menyelenggarakan pendidikan antikorupsi sebagai implementasi penguatan pendidikan karakter dalam pembelajaran, membentuk generasi bangsa yang memiliki integritas tinggi untuk mencegah terjadinya korupsi, serta membentuk generasi bangsa yang jujur, peduli, mandiri, disiplin, kerja keras, berani, tanggung jawab, dan adil serta mampu beradaptasi dengan lingkungan, berwawasan luas dan berbudi pekerti luhur.

Perbup Sukabumi Nomor 62 Tahun 2019 yang terbit pada 3 Oktober 2019 ini terdiri 14 pasal, yang menempatkan Perpres Nomor 87 Tahun 2017 dan Permendikbud Nomor 20 Tahun 2018 sebagai dasar hukumnya. Sebagai kelanjutannya, sesuai dengan Pasal 8, Kepala Dinas Pendidikan ditugaskan untuk menetapkan Petunjuk Teknis Implementasi Pendidikan Antikorupsi. Perbup ini pun diterbitkan bukan sebagai sesuatu yang imperatif hirarkis berdasarkan Pergub Jabar Nomor 60 Tahun 2019, tetapi langsung merujuk pada Perpres Nomor 87 Tahun 2017 dan Permendikbud Nonor 20 Tahun 2018.

Terbitnya berbagai produk kenegaraan dan pemerintahan tersebut merupakan kebijakan publik di bidang pendidikan atau kebijakan pendidikan, karena mengandung muatan kepentingan publik berupa harapan adanya postur birokrasi pemerintah yang terbebas dari korupsi. Ini dapat dipahami karena secara faktual akan ditemui bahwa di negara manapun, masyarakatnya akan dihadapkan pada aneka macam permasalahan yang tidak selalu dapat mereka selesaikan sendiri, termasuk di bidang pendidikan. Ketika pada tahap berikutnya
p-ISSN 2302-6960

e-ISSN 2716-165X

masalah itu menjadi perhatian publik yang luas, kemudian menjadi perhatian dan agenda pemerintah, selanjutnya melalui serangkaian proses politik dan atau administratif diputuskan dan diikuti tindakan aktual untuk kepentingan publik, sehingga lahirlah kebijakan publik (public policy).

Kebijakan publik menurut Gerston adalah the combination of basic decisions, commitments, and actions made by those who hold or influence government positions of authority' (2010:7). Post dkk. mengemukakannya sebagai 'a plan of action undertaken by government officials to achieve some broad purpose affecting a substansial segment of a nation's citizens' (1999:172). Dengan rumusan yang tidak begitu beda, yang titik tekannya pada pilihan pemerintah, menurut Dunn kebijakan publik adalah 'long series or more less related choices (including decision not to act) made by governmental bodies and officials, are formulated in issue areas which range from defence, energy and health to education, welfare and crime control' (1981:47). MacRae Jr. dan Wilde mendefinisikannya sebagai 'a policy made by government. Policy is a chosen course of significantly affecting large numbers of people' (1989:3). Pakar kebijakan publik lainnya, Anderson menyebutkan bahwa kebijakan publik adalah 'those policies developed by governmental bodies and officials'. Non governmental actors and factors may, of course, influence policy development' (1978:3).

Permasalahan korupsi memerlukan penanganan yang memadai, yang diantaranya melalui proses pendidikan, dengan menerbitkan kebijakan pendidikan. Montessori mengemukakan bahwa pendidikan antikorupsi merupakan kebijakan pendidikan yang tidak bisa lagi ditunda pelaksanaannya di sekolah secara formal. Jika dilaksanakan sebagaimana mestinya maka dalam jangka panjang pendidikan antikorupsi akan mampu berkontribusi terhadap upaya pencegahan terjadinya tindakan korupsi sebagaimana pengalaman negara lain (2012:300).

Pembahasan tentang karakteristik kebijakan pendidikan karakter dan pendidikan antikorupsi antara lain dapat dlihat dari maksud dan tujuan pengaturannya sebagaimana diatur dalam beberapa regulasi pemerintah. Sebagaimana terlihat dalam Pasal 3 Pergub Nomor 60 Tahun 2019 bahwa tujuannya adalah menyelenggarakan pendidikan 
antikorupsi sebagai implementasi Penguatan Pendidikan Karakter dalam pembelajaran; membentuk generasi bangsa yang memiliki integritas tinggi untuk mencegah terjadinya korupsi; dan membentuk generasi bangsa yang jujur, peduli, mandiri, disiplin, kerja keras, berani, tanggung jawab, dan adil serta mampu beradaptasi dengan lingkungan, berwawasan luas dan berbudi pekerti luhur. Demikian pula Pasal 3 Perbup Sukabumi Nomor 62 Tahun 2019 menyebutkan bahwa tujuannya adalah untuk mewujudkan peserta didik yang memiliki karakter antikorupsi.

Berdasarkan pandangan para pakar serta regulasi pemerintah tersebut, maka kebijakan publik merupakan serangkaian keputusan yang ditetapkan oleh pejabat dan atau lembaga negara/pemerintah yang sebelumnya melibatkan berbagai pihak dan dilanjutkan dengan tindakan nyata sesuai dengan kewenangan yang dimiliki untuk menangani masalah publik. Dalam konteks pendidikan antikorupsi, salah satu bentuk atau wujud kebijakan publik tersebut adalah Perpres Nomor 87 Tahun 2017, Permendikbud Nomor 20 Tahun 2018, Peraturan Gubernur Jabar Nomor 60 Tahun 2019 dan Peraturan Bupati Sukabumi Nomor 62 Tahun 2019. Dalam konteks pemerintahan daerah, keberadaan peraturan daerah, peraturan kepala daerah dan keputusan kepala daerah ini disebut sebagai kebijakan daerah sebagaimana tersebut dalam UU Nomor 23 Tahun 2014 tentang Pemerintahan Daerah.

Dikatakan sebagai kebijakan publik karena semuanya lahir dari kewenangan lembaga publik dalam hal ini DPR, Presiden, Mendikbud, Gubernur Jabar dan Bupati Sukabumi untuk menangani masalah publik berkenaan dengan berbagai tuntutan dan harapan publik untuk hadirnya pemerintahan yang bersih dan terbebas dari korupsi.

\section{Hirarki Kebijakan}

Dikaitkan dan dengan mengadaptasi pandangan Bromley (1989:32-33), Perpres Nomor 87 Tahun 2017 berada pada policy level, selanjutnya dijabarkan Mendikbud dalam Permen Nomor 20 Tahun 2018 yang berada pada organizational level. Secara spesifik berkaitan dengan korupsi, di Provinsi Jawa Barat hal ini dijabarkan lebih lanjut dalam Pergub Nomor 60 Tahun 2019 dan Perbup Sukabumi Nomor 62 Tahun 2019 yang berada pada operational level. Meskipun antara Pergub Jabar dengan Perbup
p-ISSN 2302-6960

e-ISSN 2716-165X

Sukabumi tidak ada hubungan struktural langsung dalam kewenangan pembentukannya, tetapi secara substansial keduanya berkaitan langsung dengan substansi pendidikan antikorupsi.
Keterlibatan
para
pejabat

negara/pemerintah sebagai aktor kebijakan pada domain negara/pemerintah ketika menetapkan kebijakan pendidikan antikorupsi ini merupakan bagian dari institutional arrangement yang menunjukkan keterhubungan antar aktor yang terlibat. Howlett dan Ramesh menyebutkan bahwa policies are made by policy subsystems consisting of actors deaking with a public problem. Policy subsystems are forums where actors discuss policy issues and persuade and bargain in pursuit of their interests. These interactions, however, occur in the context of various institutional arrangeements surrounding the policy process and affecting how the actors pursue their interests and ideas and the extent to which their efforts succeed (1995:51).

Ketika masuk tahap implementasi, semua produk kebijakan tersebut menimbulkan pola-pola interaksi yang berlangsung pada tataran pelaksana kebijakan yaitu lembaga pendidikan. Demikian pula diantara guru sebagai aktor kebijakan pendidikan antikorupsi dan peserta didik di setiap sekolah sebagai target kebijakan. Pada tahapan ini tentu saja akan ada berbagai umpan balik dari para pimpinan sekolah dan guru sebagai implementor kebijakan dan sasaran kebijakan ketika pendidikan antikorupsi ini diiimplementasikan. Sebagai bagian dari siklus kebijakan publik, selanjutnya terdapat tuntutan untuk adanya evaluasi obyektif terhadap aspek implementasinya termasuk masukan dari para pemangku kepentingan kebijakan lainnya sebagai dasar revisi kebijakan pendidikan antikorupsi di masa yang akan datang.

Perspektif hirarki kebijakan publik, terbitnya UU Nomor 20 Tahun 2003 dan Perpres Nomor 87 Tahun 2017 ini merupakan pedoman bagi kebijakan pendidikan antikorupsi yang ditetapkan penyelenggara negara level nasional dan mengikat semua stakeholders termasuk penyelenggara negara di level pemerintah daerah. Selain itu, selaras pula dengan prinsip hierarki sebagaimana diatur dalam Pasal 7 ayat (2) UU Nomor 12 Tahun 2011 tentang Pembentukan Peraturan Perundang-undangan, bahwa penjenjangan 
setiap jenis peraturan perundang-undangan didasarkan pada asas bahwa peraturan perundang-undangan yang lebih rendah tidak boleh bertentangan dengan peraturan perundang-undangan yang lebih tinggi. Hal ini sejalan pula dengan yang dikemukakan pakar kebijakan publik, Anderson, bahwa salah satu ciri kebijakan publik adalah 'in its positive form is based on law and is authoritative' (1978:4).

Terbitnya Perpres Nomor 87 Tahun 2017 meskipun tidak secara khusus merupakan sesuatu yang imperatif dan atributif berdasarkan ketentuan undangundang berkenaan dengan pendidikan, tetapi dalam konsideran "menimbang"nya sangat eksplisit disebutkan tentang arti penting pendidikan karakter. Pendidikan antikorupsi sangat beririsan dengan pendidikan karakter yang berbagai aspeknya telah diatur dalam perpres tersebut. Secara skematis, hirarki dan proses kebijakan pendidikan karakter dan pendidikan antikorupsi ini dapat divisualisasikan sebagai berikut :

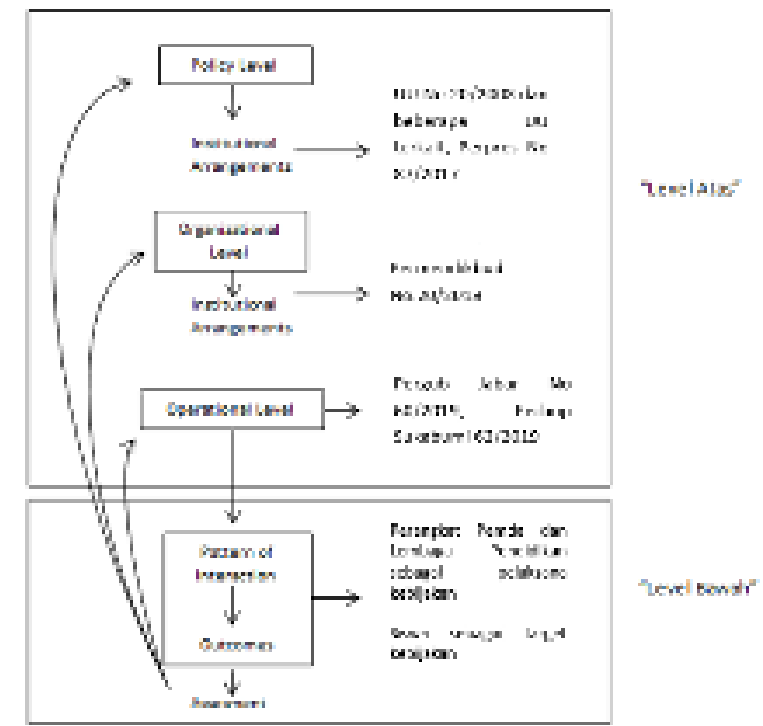

Sumber : Adaptasi dari Bromley, (1989:3233)

Gambar 1. Hirarki Kebijakan Pendidikan Antikorupsi

3. Relasi Dalam Sistem Kebijakan Pendidikan Antikorupsi

Terbitnya perpres, permen, pergub dan perbup berkaitan dengan pendidikan antikorupsi ini dari perspektif kebijakan publik menunjukkan adanya relasi interdependensi antara lembaga negara/pemerintah dengan isu yang sedang menjadi perbincangan di lingkungannya. Hal ini sejalan dengan apa yang dikemukakan Robert Eyestone bahwa kebijakan publik sebagai "the relationship of a government unit to its environment' (Anderson, 1978:2). Hal ini selaras pula dengan yang dikemukakan Gerston tentang lima komponen kebijakan publik yaitu isu (issues), aktor (actor), sumberdaya (resource), lembaga (institution) dan tingkat pemerintahan (the level of government). Dikemukakan lebih lanjut bahwa 'issues that appear on the public agenda; actors who present, interpret, and respond to those issues; resources affected by those issues; institutions that deal with issues; and the levels of government that address issues' (2010: 8).

Terbitnya berbagai kebijakan yang langsung maupun tidak langsung berkenaan dengan pendidikan antikorupsi ini, dengan merujuk pada pendapat Bromley merupakan bagian dari institutional arrangement sesuai dengan kewenangan yang dimiliki kelembagaan negara/pemerintah di tingkat pusat dan daerah. Selain itu, hal ini sejalan dengan yang dikemukakan Dunn tentang sistem kebijakan (The Policy System) bahwa $A$ Policy System, or the overall institutional pattern within which policies are made, involves interrelationship among three elements : public policies, policy stakeholders, and policy environments.' (1981:47). Terbitnya UU Nomor 20 Tahun 2003 dan beberapa undang-undang lain terkait dengan pendidikan, Perpres Nomor 87 Tahun 2017, Permendikbud Nomor 20 Tahun 2018, Pergub Jabar Nomor 60 Tahun 2019, dan Perbup Sukabumi Nomor 62 Tahun 2019, jelas pada dasarnya merupakan wujud kebijakan publik (Public Policy).

Hal ini merupakan respon terhadap lingkungan kebijakan (Policy Environment) berupa kondisi makin tumbuhnya kesadaran dan tuntutan masyarakat terhadap hadirnya pemerintahan yang bersih dan terbebas dari korupsi. Berkaitan dengan lingkungan kebijakan, Anderson mengemukakan bahwa demands for policy actions are generated in the environment and transmitted to the political; at the same time, the environment places limits and constraints upon what can be done by policy makers. Included in the environment are such geographical characteristics, political culture, social structure, and the economis system (1978:27). Berkenaan dengan adanya tuntutan publik kepada pemerintah tentang penanggulangan korupsi serta keputusan pemerintah sebagai responnya, ini selaras dengan yang dikemukakan Anderson tentang lima kategori 
kebijakan untuk dapat memahami secara utuh kebijakan tersebut. Kategori tersebut adalah 'policy demands, policy decisions, policy statements, policy output dan policy outcome' (1978:4).

Berdasarkan data korupsi saat ini sudah berada dalam tahap mengkhawatirkan, sehingga nyaris tidak ada satu segmen kehidupanpun yang tidak terjangkiti virus moral yang sangat merugikan keuangan dan perekonomian negara ini. Merujuk pada laporan pemantauan ICW, aneka modus korupsi pada semester 1 tahun 2020 terlihat pada table berikut.

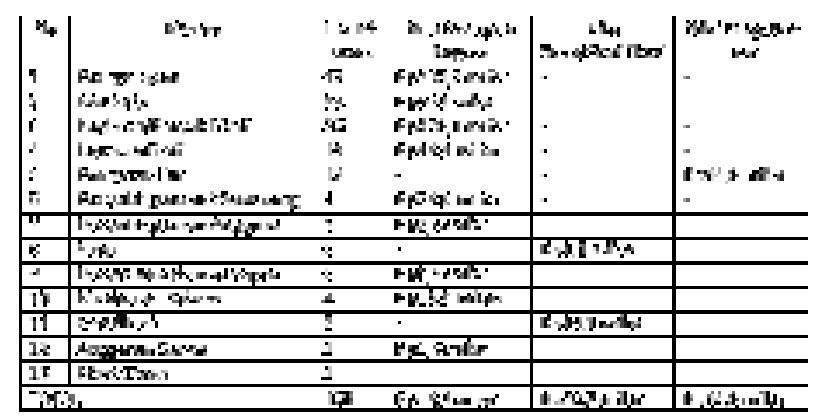

Sumber: Indonesia Corruption Watch 2020

Tabel 1. Pemetaan Korupsi Berdasarkan Modus

Suatu ketika bukan hal yang mustahil bila perilaku korup yang telah mandarah daging dan menyerang ke segala penjuru kehidupan berbangsa, termasuk ke sektor pemerintahan, akan melahirkan budaya permisif di kalangan masyarakat. Apabila ini terjadi, maka makin besar tantangan dan permasalahan yang dihadapi para penegak hukum. Hal ini juga berarti tantangan yang sangat besar bagi seluruh aktor pendidikan untuk turut berkontribusi dalam upaya besar pencegahan dan pemberantasan korupsi ini.

Terbitnya semua regulasi berkenaan dengan pendidikan antikorupsi ini karena peran para pemangku kepentingan (stakeholders) kebijakan pendidikan karakter dan pendidikan antikorupsi, yang terdiri dari institusi dan aktor-aktor negara/pemerintah (governmental actors) dan aktor di masyarakat (nongovernmental actors). Aktor negara seperti pejabat negara, legislator, dan birokrat pemerintah di bidang pendidikan serta aktor di masyarakat, diantaranya para pengamat pendidikan, pegiat antikorupsi, semuanya berada pada elemen sendiri yang dinamakan pemangku kepentingan kebijakan (Policy Stakeholders). Kedudukan para pembuat kebijakan (policy maker) yang berada tataran lembaga legislatif maupun
p-ISSN 2302-6960

e-ISSN 2716-165X

eksekutif di pusat dan daerah, yang dalam konteks sistem kebijakan merupakan bagian dari sistem politik ini, diatur tugas, wewenang dan kewajibannya dalam berbagai undangundang yang mengaturnya. Dalam kaitan ini, tampak bahwa negara atau pemerintah sangat strategis dalam pembentukan kebijakan publik ini. Hal ini sejalan dengan pandangan Michael bahwa 'without the existence of the state, the public policy making process, as we know it, could not operate. It is the state that provides the basis for collective decision making, the application and enforcement of those decisions, and the means for changing or altering others' (2006:11). Antara regulasi pendidikan karakter dan pendidikan antikorupsi sebagai kebijakan publik dengan para pemangku kepentingan kebijakan dan lingkungan kebijakan ini terjadi hubungan saling pengaruh mempengaruhi.

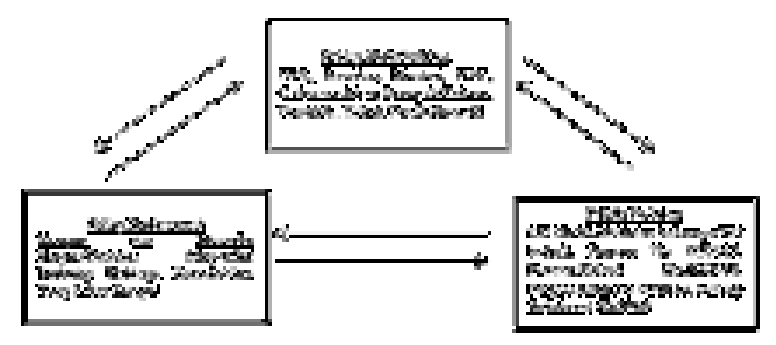

Sumber : Adaptasi dari Dunn (1981:47)

Gambar 2. Regulasi Pendidikan Antikorupsi Dalam Sistem Kebijakan

Berkenaan dengan aktor kebijakan (policy actor) menurut Howlett dan Ramesh, the term "actor" includes both sate and societal actors, some of whom are intimately involved in the policy process while other are only marginally so. Actors in the policy process may be either individual or groups (Howlett \& Ramesh, 1995:51). Sebagai aktor kebijakan, Presiden berkedudukan sebagai kepala pemerintahan yang menetapkan Perpres Nomor 87 Tahun 2017, Gubernur Jabar yang menetapkan Pergub Nomor 60 Tahun 2019 dan Bupati Sukabumi yang menetapkan Perbup Nomor 62 Tahun 2019. Ketiganya merupakan aktor individual dalam domain negara/pemerintah sesuai dengan otoritas yang melekat padanya. Demikian pula aktor lain turut berperan, baik yang berada pada tatanan pemerintahan ataupun masyarakat, diantaranya yaitu para kepala Dinas Pendidikan dan jajarannya, kepala sekolah dan guru, pengamat pendidikan dan lembaga swadaya masyarakat yang bergerak di bidang pendidikan. 
Institusi kebijakan as the structures and organization of the state, society and the international system (Howlett \& Ramesh, 1995:51). Aktor kebijakan yang menurutnya ada lima ketegori, yaitu elected officials, appointed officials, interest group, research organizations, and mass media (Howlett \& Ramesh, 1995:52) berada dan beraktivitas dalam berbagai institusi yang ada dalam sistem kebijakan. Lahirnya Perpres, Permendikbud, Pergub Jabar dan Perbup Sukabumi tidak terlepas dari keterlibatan tiap aktor pada berbagai institusi dengan derajat yang beraneka ragam. Demikian pula ketika kebijakan tersebut diimplementasikan, yang menuntut keterlibatan para aktor di institusi pendidikan. Lembaga pendidikan, termasuk sekolah menjadi institusi strategis dan menentukan bagi upaya pencegahan dan pemberantasan korupsi dengan program pendidikan antikorupsi.

Sekolah menurut Harmanto sebagai lingkungan kedua bagi siswa dapat menjadi tempat pembangunan karakter dan watak. Caranya, sekolah memberikan nuansa dan atmosfer yang mendukung upaya untuk menginternalisasikan nilai dan etika yang hendak ditanamkan, termasuk di dalamnya perilaku antikorupsi (Harmanto \& A.r, 2013:157). Berbagai metode, teknik dan pendekatan untuk mewujudkan pendidikan antikorupsi telah dipilih dan ditetapkan, termasuk melalui serangkaian kajian ilmiah dari para akademisi. Dalam kaitan ini, Subkhan mengemukakan bahwa pendidikan antikorupsi selama ini tampak berjalan sebatas teoritis yang dipelajari dalam beberapa mata pelajaran di sekolah, perguruan tinggi atau program-program khusus tertentu. Orientasi praktik pendidikan antikorupsi belum sampai pada membelajarkan sungguh-sungguh bagaimana siswa harus bersikap dalam menolak praktik korupsi dan sistem yang toleran terhadap perilaku korupsi (2020:15).

\section{KESIMPULAN}

Berbagai macam permasalahan yang dirasakan publik, setelah melalui serangkaian proses dalam tatanan infrastruktur maupun suprastruktur politik, ditetapkan menjadi kebijakan publik, diantaranya kebijakan publik tentang pendidikan karakter dan pendidikan antikorupsi. Terdapat hubungan yang erat antara administrasi publik, kebijakan publik, pendidikan karakter dan pendidikan
p-ISSN 2302-6960

e-ISSN 2716-165X

antikorupsi sebagai salah satu area substantif kebijakan publik. Bahwa produk kebijakan publik tentang atau yang berkaitan dengan pendidikan karakter dan pendidikan antikorupsi yang meliputi UU Nomor 20 Tahun 2003, dan beberapa UU terkait, Perpres 87 Nomor Tahun 2017, Permendikbud Nomor 20 Tahun 2018, Pergub Jabar Nomor 60 Tahun 2019, dan Perbup Sukabumi Nomor 62 Tahun 2019, menunjukkan adanya tingkatan struktural dalam tatanan kebijakan publik secara keseluruhan. Antara pembentuk kebijakan pendidikan karakter dan pendidikan antikorupsi sebagai aktor kebijakan dengan institusi dan lingkungan terjadi hubungan timbal balik.

\section{E. DAFTAR PUSTAKA}

Anderson, J. E. (1978). Public Policy-Making. Second Edition. Holt, Rinehart and Winston.

Bromley, D. W. (1989). Economic Interest and Institution. The Conceptual Foundation of Public Policy. Basil Blackwell Inc.

Dunn, W. N. (1981). Public Policy Analysis: An Introduction. Prentice Hall Inc. Englewood Cliffts.

Gerston, L. N. (2010). Public Policy Making. Process and Principles. Third Edition. E Sharpe.

Harmanto, \& A.r, E. D. (2013). Pendidikan Antikorupsi dalam Pembelajaran PKn Sebagai Penguat Karakter Bangsa. Jurnal Pendidikan Dan Pembelajaran (JPP), 19(2), 157-171.

Howlett, M., \& Ramesh, M. (1995). Studying Public Policy: Policy Cycles and Policy Subsystems. Oxford University Press.

Lawrence, A. T., \& Webber, J. (2014). Business and Society. Stakeholders, Ethics, and Public Policy. McGraw-Hill International Edition.

MacRae, J. D., \& James, W. (1989). Policy Analysis for Public Decisions. University Press of America.

Marzuki. (2015). Penelitian Hukum Edisi Revisi. Prenadamedia Group.

Michael, E. (2006). Public Policy: The 
Competitive Framework. Oxford

University Press.

Montessori, M. (2012). Pendidikan Antikorupsi

Sebagai Pendidikan Karakter Di

Sekolah. Jurnal Demokrasi, 11(1),

Article 1.

http://ejournal.unp.ac.id/index.php/jd/arti

cle/view/2561

Post, J. E. (1999). Business and Society. Corporate Strategy, Public Policy, Ethics. Irwin McGraw-Hill.

Soekanto, S., \& Mamudji, S. (2015). Penelitian Hukum Normatif. Suatu Tinjauan Singkat. PT RajaGrafindo Persada.

Subkhan, E. (2020). View of Pendidikan Antikorupsi Perspektif Pedagogi Kritis. KPK JURNAL INTEGRITAS: Jurnal Antikorupsi, 6(1), 15-30.

UU Nomor 20 Tahun 2003 tentang Sistem Pendidikan Nasional,

UU Nomor 23 Tahun 2014 tentang Pemerintahan Daerah

UU Nomor 12 Tahun 2011 tentang Pembentukan Peraturan Perundangundangan

Perpres Nomor 87 Tahun 2017 tentang Penguatan Pendidikan Karakter

Permendikbud Nomor 20 Tahun 2018 tentang Penguatan Pendidikan Karakter Pada Satuan Pendidikan Formal

Peraturan Gubernur (Pergub) Jawa Barat Nomor 60 Tahun 2019 tentang Penyelenggaraan Pendidikan Antikorupsi Pada Satuan Pendidikan Yang Menjadi Kewenangan Daerah Provinsi Jawa Barat,

Peraturan Bupati (Perbup) Sukabumi Nomor 62 Tahun 2019 tentang Pendidikan Antikorupsi Pada Satuan Pendidikan Jenjang Pendidikan Anak usia Dini, Sekolah Dasar, Sekolah Menengah Pertama dan Pendidikan Kesetaraan

Laporan Pemantauan Tren Peningkatan Kasus Korupsi Semester I 2020, Divisi Hukum Monitoring Peradilan, Indonesia Corruption Watch 2020 